\title{
PERAN CARA KARANTINA IKAN YANG BAIK (CKIB) DALAM PENCEGAHAN PENYAKIT VIRUS PADA UDANG VANAME (Litopenaeus vannamei) DI PROVINSI LAMPUNG
}

\author{
Sumino ${ }^{1}$, Ishaaq Saputra ${ }^{2}$, Herman Mude ${ }^{1}$ \\ ${ }^{1}$ Balai KIPM Lampung, Bandar Lampung, Indonesia \\ ${ }^{2}$ Balai Besar KIPM Jakarta I, Tangerang, Banten, Indonesia \\ E-mail: isaputra.6m2@gmail.com
}

Received July 2020, Accepted September 2020

\begin{abstract}
ABSTRAK
Provinsi Lampung merupakan salah satu wilayah penghasil udang vaname terbesar di Indonesia. Produktivitas udang vaname di Lampung mengalami pasang surut, salah satunya dikarenakan serangan penyakit golongan virus seperti WSSV, IHHNV dan IMNV. Penelitian ini bertujuan untuk mengevaluasi status penyebaran penyakit WSSV, IHHNV dan IMNV pada udang vaname dan mengevaluasi keefektifan penerapan Cara Karantina lkan yang Baik (CKIB) dalam menekan penyebaran virus tersebut di Provinsi Lampung. Pada penelitian ini, dilakukan pengumpulan data pengujian pada tahun 2019 yang berasal dari sampel umum, kegiatan pemantauan Penyakit Ikan Karantina (PIK) dan kegiatan CKIB, kemudian dilakukan analisa secara deskriptif. Hasil penelitian menunjukkan bahwa di Provinsi Lampung masih terdapat penyakit virus udang yaitu WSSV, IHHNV dan WSSV yang tersebar di sentra budidaya udang vaname. Dari sejumlah 624 total sampel pengujian, sebanyak $8.97 \%$ positif terinfeksi penyakit virus. WSSV memiliki tingkat infeksi terbesar yaitu $58.9 \%$. Sedangkan untuk IMNV dan IHHNV masing-masing sebesar $33.9 \%$ dan $7.1 \%$. Berdasarkan asal sampel pengujian dapat diketahui bahwa sampel yang diperoleh dari pembudidaya yang telah menerapkan CKIB menunjukkan hasil negatif untuk ketiga jenis virus target tersebut. Hal tersebut memberikan gambaran bahwa dengan penerapan CKIB secara konsisten dapat mengurangi tingkat penyebaran penyakit virus pada budidaya udang vaname.
\end{abstract}

Kata Kunci : CKIB, Lampung, Vaname, Virus

\section{ABSTRACT}

ROLES OF GOOD QUARANTINE PRACTICES IN THE SPREAD OF VIRUS DISEASES OF VANNAMEI SHRIMP (Litopenaeus vannamei) IN PROVINCE OF LAMPUNG. Lampung is one of the largest whiteleg shrimp (L. vannamei) producers in Indonesia. Whiteleg shrimp productivity in Lampung has fluctuated, one of which is due to infectious by virus disease. This study evaluated the current status of WSSV, IHHNV and 
WSSV diseases in whiteleg shrimp cultivation and assesses the effectivity of CKIB implementation in preventing the outspread of the shrimp viral diseases in Lampung. In this study, data from general samples, diseases monitoring/surveillance and Good Quarantine Practices (GQP) activities in 2019 were collected and then analyzed descriptively. Here, were report the emergence of shrimp viral diseases, e.g. WSSV, IHHNV and WSSV, in whiteleg shrimp aquaculture in Lampung. Infected shrimp were found in $8.97 \%$ of 624 tested samples. WSSV has the highest infection rate (58.9\%) and followed by IMNV and IHHNV (33.9\% and $7.1 \%$, respectively). The samples collected from whiteleg shrimp aquaculture centre that applied GQP showed negative viral disease infection. These results demonstrate that consistent application of GQP in whiteleg shrimp cultivation can prevent the spread of shrimp viral disease.

Keywords : GQP, Lampung, Vaname, Virus

\section{PENDAHULUAN}

Udang merupakan komoditas utama perikanan yang telah ditetapkan oleh pemerintah melalui Kementerian Kelautan dan Perikanan. Budidaya udang memiliki sejarah yang panjang di Indonesia. Pada awal masa budidayanya, komoditas utama budidaya udang adalah udang windu (Penaeus monodon). Budidaya udang windu mengalami masa kejayaannya pada tahun 1980an hingga awal 2000 (Nurhajarini et.al 2017). Udang yang disebut juga dengan udang harimau ini juga banyak dibudidayakan di negara-negara lain seperti Malaysia, india, China, Filipina, Thailand dan Vietnam. Akan tetapi, dengan merebaknya penyakit bintik putih yang menyerang budidaya udang windu, secara perlahan produksi budidaya udang ini tertekan secara global dengan jumlah produksi berkisar 700.000 ton pertahun selama 2001-2016 (FAO, 2020).

Udang vaname merupakan udang asli dari perairan Amerika serikat. Sistem produksi udang vaname secara intensive telah dimulai pada tahun 1991 di Hawaii, Amerika Serikat (Wyban \& Sweeney, 1991). Udang ini diketahui memiliki beberapa keunggulan seperti lebih tahan terhadap penyakit, memiliki pertumbuhan yang lebih baik dan lebih mudah beradaptasi. Berdasarkan keunggulan tersebut hingga pada akhirnya domestikasi udang vaname dilakukan secara masif di negara-negara penghasil udang termasuk Indonesia (Taukhid \& Nur'aini, 2008). Dengan adanya domestikasi udang putih ini di seluruh negara penghasil udang budidaya, produksi udang secara global pun meningkat dari 280.298 ton pada 2001 menjadi 4.115.286 pada tahun 2016 (FAO, 2020). China merupakan negara penghasil budiaya perikanan termasuk udang putih terbesar di dunia dengan produksi sebesar 49.2 juta ton pada 2016 atau $61.5 \%$ dari total hasil budidaya ikan di Asia. Sedangkan negara lain yang merupakan penghasil utama budiaya ikan adalah India, Indonesia, Vietnam dan Bangladesh (FAO, 2018).

Indonesia merupakan negara terbesar kedua di dunia sebagai penghasil udang vaname dengan jumlah produksi 919.988 ton pada tahun 
2017 (Nainggolan et.al 2018). Produksi udang vaname tersebar di beberapa provinsi di Indonesia antara lain Aceh, Sumatera Selatan, Lampung, Banten, Jawa Tengah, Jawa Barat, Makasar dan beberapa provinsi lain. Provinsi Lampung merupakan salah satu lokasi budidaya udang vaname yang terbesar di Indonesia dengan jumlah produksi udang pada tahun 2017 tercatat sebesar 59.405 ton (Nainggolan et.al 2018). Jumlah produksi tersebut mengalami kenaikan dan penurunan beberapa tahun terakhir yang disebabkan karena adanya wabah penyakit virus. Udang vaname merupakan host dari beberapa jenis penyakit virus seperti Infectious Myonecrosis (IMN), Infectious Hypodermal and Hematopoietic Necrosis (IHHN) dan White Spot Disease (WSD) (OIE, 2006).

Terjadinya wabah penyakit udang membuat kerugian yang sangat besar hingga jutaan dollar di seluruh dunia (Flegel, 2006; Lightner, 2011). IMNV merupakan jenis virus RNA dengan untaian ganda yang mengakibatkan penyakit IMN pada udang penaeid (OIE, 2006). IMNV pertama kali dilaporkan di Brazil pada budidaya udang pada tahun 2006 (Costa et.al 2009). Di Indonesia, IMNV dilaporkan terjadi untuk pertamakali di budidaya udang di Situbondo, Jawa Timur pada tahun yang sama. Infeksi virus ini memiliki kesamaan dengan yang teah dilaporkan terjadi di Brazil (Senapin et.al 2007). Beberapa penelitian tentang virus ini telah dilakukan (Nur'aini et.al 2007; Rekasana et.al 2013; Sarah et.al 2018; Zaujat et.al 2016). Sedangkan IHHN adalah penyakit virus pada udang yang disebabkan oleh virus IHHNV dengan type single-stranded DNA (OIE, 2006). Pertama kali muncul, IHHNV ditemukan pada budidaya udang biru (L. styloristris) di Hawaii pada tahun 1980-an. Jenis penyakit ini memang tidak mengakibatkan kematian yang signifikan pada budidaya udang, akan tetapi lebih berdampak terhadap pertumbuhan udang. Selain menginfeksi udang biru, penyakit ini juga menginfeksi udang putih $L$. vaname di lokasi yang sama di Asia Tenggara, IHHNV pertamakali menyerang budidaya udang windu di Filipina. Hal ini disinyalir terkait importasi induk udang windu di negara tersebut untuk keperluan peningkatan produksi satu dekade sebelumnya (Lightner, 2011). Keberadaan penyakit ini di Indonesia telah dilaporkan oleh (Mulyadi et.al 2013; Sriwulan \& Anshary, 2011).

Selain IHHN, terdapat penyakit bintik putih (White Spot Disease) yang juga penting dalam kegiatan budidaya udang. Penyakit ini disebakan oleh virus jensi double stranded DNA dengan nama patogen White Spot Syndrome Virus. Penyakit bintikputih ini pertamakali dilaporkan terjadi di Jepang pada tahun 1993 pada budidaya Marsupenaeus japonicus (Inouye et.al 1994; Nakano et.al 1994). Penyakit yang sangat merugikan pada kegiatan budidaya ini menyebar ke berbagai sentra industri udang di Asia dan India. Penyebaran di beberapa negara terjadi karena adanya perpindahan udang hidup. Di Australia dan Spanyol, penyakit menyebar melalui pakan beku untuk induk udang (Lightner, 2011). Penyakit WSSV di Indonesia telah menyerang budidaya udang windu pada tahun 19902000 (Rukyani, 2001). Meskipun demikian, penggantian spesies budidaya dari $P$. monodon ke $L$. vaname tidak mengurangi dampak signifikan dari penyakit bintih putih ini. Beberapa studi tentang epidmiologi tentang 
WSSV telah dilakukan (Koesharyani et.al 2015; Koesharyani et.al 2012; Latritiani et.al 2017; Muliani et.al 2007; Rahma et.al 2014; Yanti et.al 2017).

Badan Karantina Ikan, Pengendalian Mutu dan Keamanan Hasil Perikanan merupakan organisasi di Kementerian Kelautan dan Perikanan yang memiliki fungsi pengawasan dan pencegahan terhadap penyakit ikan tertentu termasuk virus pada udang vaname. Salah satu wujud pengendalian nyata yang telah dilakukan oleh BKIPM dalam hal ini adalam dengan adanya sertifikasi Cara Karantina Ikan yang Baik (CKIB). Kegiatan ini memiliki tujuan utama untuk menjamin bahwa ikan yang dilalulintaskan bebas dari hama dan penyakit ikan berbahaya, sehingga diharapkan penyebaran penyakit yang berbahaya dapat ditekan. Berdasarkan Keputusan Menteri Kelautan dan Perikanan Republik Indonesia No. 58 tahun 2016 Tentang Status Area tidak bebas penyakit ikan karantina di wilayah NKRI, dinyatakan bahwa di Propinsi Lampung tidak bebas untuk penyakit IMN, WSD dan IHHN. Mengingat begitu pentingnya status penyakit pada budidaya udang khususnya penyakit yang disebabkan oleh virus di wilayah Lampung, sangat penting untuk melakukan monitoring dan surveilen penyakit pada budiaya udang serta maupun keefektifitasan penerapan CKIB pada unit budidaya. Akan tetapi, meskipun diketahui telah dilakukan monitoring status penyakit virus pada udang di Provinsi Lampung, ketersediaan data tersebut masih sulit untuk ditemukan. Oleh karena itu, penelitian tentang status penyakit pada budidaya udang di Provinsi Lampung perlu untuk dilakukan. Adapun tujuan dari penelitian ini adalah untuk mengetahui status penyakit yang disebabkan virus khususnya WSD, IHHN dan IMN pada budidaya udang vaname dan tingkat keefektifitasan penerapan kegiatan CKIB di Provinsi Lampung.

\section{MATERI DAN METODE}

\section{Waktu Penelitian}

Data penelitian ini berasal dari hasil pengujian sampel udang vaname yang dikumpulkan pada tahun 2019 baik sampel pengujian umum, pemantauan PIK maupun CKIB. Jenis sampel yang didata adalah sampel udang vaname pada semua stadia meliputi naupli, benur, naupli maupun udang. Pengujian dilakukan di Laboratorium Balai KIPM Lampung dengan metode Polymerase Chain Reaction (PCR). Adapun jenis PCR yang digunakan adalah PCR konvensional. Primer PCR yang digunakan yaitu IQ2000 (Genereach, Taiwan) sesuai dengan target penyakit.

\section{Sampel Pengujian}

Sampel pengujian pada kegiatan penelitian ini dikategorikan menjadi sampel umum, pemantauan dan CKIB. Sampel umum merupakan sampel yang berasal dari masyarakat yang secara sukarela melakukan pengujian 
untuk kepentingan pribadi. Sedangkan sampel pemantauan yaitu sampel yang diperoleh dari kegiatan pemantauan HPIK yang merupakan kegiatan rutin dilakukan untuk memonitoring kondisi penyakti pada budidaya ikan/udang. Sampel CKIB yaitu sampel yang berasal dari kegiatan surveilen terhadap penerapan CKIB pada unit budidaya udang.

\section{Metode Pengujian}

Metode yang digunakan dalam pengujian sampel udang yaitu konvensional PCR yang terdiri dari proses ekstraksi, amplifikasi, elektroforesis dan dokumentasi hasil (Latritiani et.al 2017; Rahma et.al 2014). Ekstraksi sampel untuk pengujian virus WSSV dan IHHNV diawali dengan mengambil potongan sampel dengan ukuran 1-2 cm dimasukkan

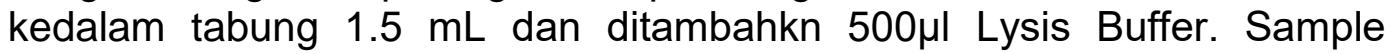
kemudian dihancurkan hingga halus. Setelah itu dilakukan inkubasi pada suhu $95^{\circ} \mathrm{C}$ selama 10 menit dan kemudian disentrifuse $12.000 \mathrm{rpm}$ selama 10 menit. Sebanyak $200 \mu \mathrm{l}$ sampel dipindahkan kedalam tabung baru dan kemudian ditambahkan $400 \mu \mathrm{l}$ ethanol (90\%). Tabung kemudian di vortex sesaat dan sentrifuse $12.000 \mathrm{rpm}$ selama 5 menit. Ethanol dalam tabung dibuang dan pellet dikeringkan sesaat pada suhu ruang. Pelet DNA kemudian dilarutkan dengan ddH2O atau TE Buffer. Sedangkan ekstraksi untuk sampel pengujian IMNV dilakukan dengan memasukkan sampel ke dalam tubung $(1.5 \mathrm{ml})$ kemudian tambahkan $500 \mu \mathrm{l}$ RNA extraction solution. Sampel dihancurkan dan setelah itu didiamkan pada suhu ruang selama 5 menit. Sebanyak $100 \mu$ kloroform ditambahkan dan kemudian dilakukan vortex selama 20 detik. Setelah itu, sampel didiamkan pada suhu ruang kembali selama 3 menit, kemudian dilakukan sentifuse dengan kecepatan 12.000 rpm selama 15 menit. Sebanyak $200 \mu$ bagian bening sampel dalam tabung dipindahkan kedalam tube yang baru dan $200 \mu \mathrm{l}$ isopropanol. Vortex sesaat, kemudian sentrifuse dengan kecepatan 12.000 rpm selama 10 menit. Setelah isopropanol dibuang, pellet RNA dibilas dengan $500 \mu$ lethanol $75 \%$, kemudian spindown selama 5 menit dengan kecepatan 9.000 rpm untuk memperoleh pellet RNA. Setelah itu ethanol dibuang dan tabung dikering anginkan untuk memperoleh pellet. Pelet RNA dilarutkan menggunakan ddH2O sebanyak $500 \mu \mathrm{l}$. Ekstrak DNA dan RNA yang dihasilkan kemudian dilanjutkan dengan proses amplifikasi dengan mengikuti profil PCR sesuai Program UnilQ Nested PCR Konvensional.

Elektroforesis diawali dengan pembuatan gel agarose $2 \%$ sebagai media elektroforesis menggunakan agarose powder (SeaKem Agarose Gel Lonza, US) dan larutan TAE Buffer 1x. Gel yang sudah siap kemudian diletakkan kedalam elektroforesis apparatus dengan posisi sumur sampel ada di kutub negatif. Larutan TAE buffer 1X dituangkan kedalam elektroforesis apparatus sampai batas maksimal TAE. Tegangan listrik untuk proses elektroforesis diatur pada posisi 100-150 volt. Pada sumuran pertama, diisi sebanyak $5 \mu$ DNA marker. Langkah selanjutnya yaitu menambahkan $2 \mu$ loading dye ke dalam amplikon kemudian secara perlahan sampel ke dalam sumuran dengan volume $5 \mu \mathrm{l}$. Untuk 
meminimalisir kontaminasi silang, amplikon sampel negatif diproses terlebih dahulu, dilanjutkan dengan amplikon sampel udang dan terakhir amplikon kontrol positif. Proses elektroforesis dilakukan selama 20 menit dan atau dihentikan ketika warna biru tua telah sampai 1/2 atau 2/3 dari gel. Gel yang telah di elektroforesis diwarnai menggunakan syber safe dengan dosis $5 \mu \mathrm{l} / 100 \mathrm{ml}$ akuades sebagai media pewarnaan. Dokumentasi hasil elektroforesis dilakukan dengan UV transiluminator (UVP Biodoc-It, US).

\section{Analisis Data Pengujian}

Hasil pengujian PCR dianalisa dengan standar acuan manual KIT dengan tingkat deteksi copy DNA sebesar $10^{1}, 10^{2}$ dan $10^{3}$. Data hasil penelitian akan di analisa secara deskriptif dan disajikan baik dalam bentuk tabel dan gambar. Pada penelitian ini tidak dilakukan analisa tingkat prevalensi. Data yang dilaporkan merupakan hasil pengujian sampel yang diuji.

\section{HASIL DAN PEMBAHASAN}

Pada penelitian yang telah dilakukan, diperoleh jumlah pengujian virus IHHNV, WSSV dan IMNV pada udang vaname di Provinsi Lampung yang berasal dari kegiatan pengujian umum, pemantauan dan CKIB adalah sebanyak 624 pengujian. Dari jumlah sampel tersebut, sebesar $8.79 \%$ memberikan hasil positif virus. Hasil penelitian ini juga menunjukkan bahwa seluruh sampel CKIB yang diuji tidak terdapat sampel memberikan hasil virus positif. Disisi lain, sampel umum dan pemantauan memiliki tingkat positif sampel sebesar $13.0 \%$ dan $23.7 \%$. Secara detail, jumlah pengujian virus dan hasil positif pengujian dapat dilihat pada Gambar 1.
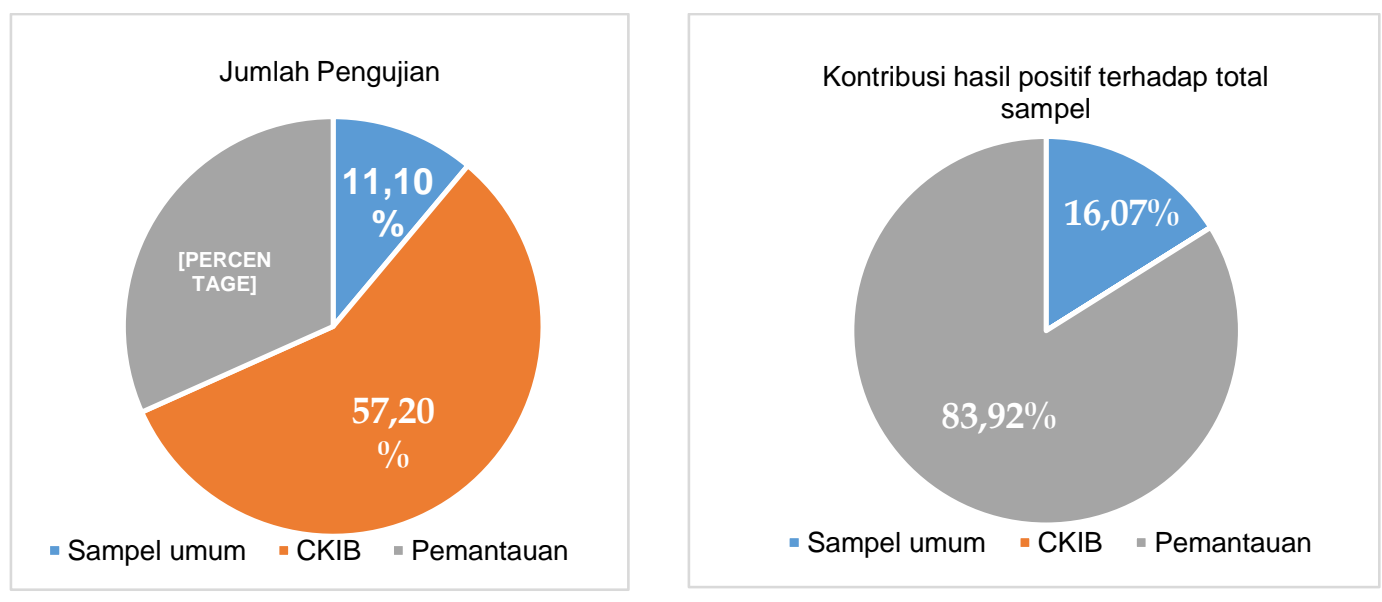

Gambar 1. Proporsi sampel pengujian berdasarkan kegiatan dan kontribusi terhadap hasil positif

Penyakit virus telah mempengaruhi kegiatan budidaya udang baik dalam skala nasional maupun secara global. Beberapa jenis penyakit 
virus pada udang telah diidentifikasi (OIE, 2006) dan menjadi perhatian utama pada industri budidaya udang (Lightner, 2011). Pada penelitian ini, diketahui bahwa di Provinsi Lampung masih terdapat penyakit WSD, IHHN dan IMN yang masing-msing disebabkan oleh WSSV, IHHNV dan IMNV. Penyakit-penyakit ini ada hampir di seluruh wilayah sentra budidaya udang di Provinsi Lampung terutama di wilayah yang berbatasan dengan laut.

Tabel 1. Lokasi asal sampel dan hasil pengujian virus

\begin{tabular}{lllccc}
\hline \multirow{2}{*}{ No } & \multirow{2}{*}{ Asal Sampel } & Kabupaten/Kota & \multicolumn{3}{c}{ Virus } \\
\cline { 3 - 5 } & & & WWSV & IHHNV & IMNV \\
\hline 1. & Sampel & Lampung Selatan & + & - & - \\
& Umum & Lampung Timur & + & - & - \\
& & Pesawaran & - & - & + \\
2. & CKIB & Lampung Selatan & - & - & - \\
& & Tanggamus & - & - & - \\
3. & Pemantauan & Pesawaran & & - & + \\
& PIK & Lampung Selatan & + & + & + \\
& & Lampung Selatan & + & - & + \\
& & Lampung Timur & + & + & + \\
& & Tanggamus & + & - & - \\
& & Pesisir Barat & + & - & - \\
\hline
\end{tabular}

Berdasarkan jenis virus yang diuji, hasil pengujian menunjukkan bahwa trend hasil yang berbeda. Pada sampel umum, sebanyak 69 pengujian telah dilakukan dan dari ketiga jenis virus yang diuji menunjukkan bahwa WSSV memiliki hasil positif tertinggi dengan jumlah $25.5 \%$ sampel positif. Sedangkan hanya sebesar $3.8 \%$ sampel memberikan hasil positif untuk virus IMNV. Adapun jumlah pengujian virus IHHNV, WSSV dan IMNV dari kegiatan pemantauan yaitu sebanyak 198 pengujian. Secara detil proporsi hasil pengujian positif pada sampel pemantauan dapat dilihat pada Gambar 2.

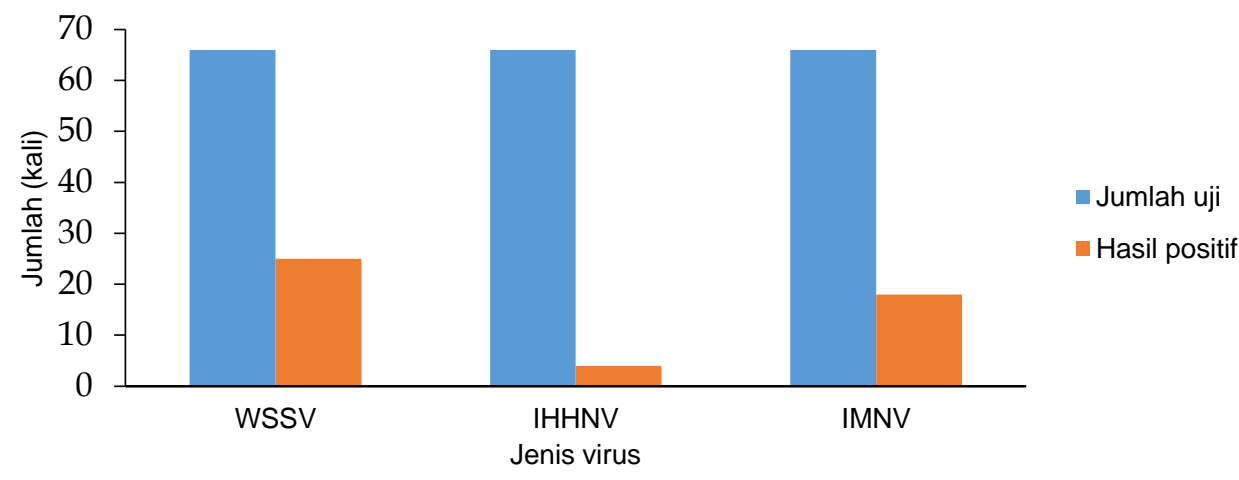

Gambar 2. Jumlah pengujian dan hasil positif pada sampel kegiatan pemantauan 
IMNV dilaporkan terjadi untuk pertamakalinya di Indonesia pada tahun 2006 dan memiliki kesamaan genetik dengan IMNV di Brazil (Senapin et.al 2007). Pada penelitian ini, tingkat kejadian hasil positif virus IMNV menempati urutan kedua setelah WSSV. Setidaknya setengah dari wilayah yang dilakukan pemantauan memberikan hasil positif terhadap virus ini. Virus ini telah ada di Indonesia sejak satu dekade yang lalu (Naim et.al 2014; Nur'aini et.al 2007; Rekasana et.al 2013; Sarah et.al 2018; Zaujat et.al 2016). Rekasana et.al (2013) melaporkan keberadaan virus IMNV di beberapa daerah sentra budidaya udang vaname di Jawa Timur dengan tingkat prevalensi $53-100 \%$. Penelitian ini mengkonfirmasi keberadaan IMNV di Provinsi Lampung ada penelitian yang lain (Sudjito et.al 2014). Pada penelitiannya, IMNV di Provinsi Lampung memiliki kemiripan genetik hingga lebih dari 99\% dengan IMNV yang ada di Brazil (Naim et.al 2014). Penelitian terbaru yang dilakukan oleh Mai et.al (2019), menunjukkan bahwa sampel udang yang terinfeksi IMNV di wilayah Situbondo merupakan genotype baru dari IMNV. Infeksi IMNV pada media pemeliharaan dengan salinitas rendah (15-25 ppt) mengakibatkan tingkat infeksi yang lebih tinggi. Kondisi pemeliharaan dengan salinitas $30 \mathrm{ppt}$ merupakan kondisi ideal yang dapat menekan terjadinya virus ini (Mita et.al 2016).

IHHN adalah penyakit virus pada udang yang disebabkan oleh virus IHHNV dengan type single-stranded DNA (OIE, 2006). Pertama kali muncul, IHHNV ditemukan pada budidaya udang biru (L. styloristris) di Hawaii pada tahun 1980-an. Jenis penyakit ini memang tidak mengakibatkan kematian yang signifikan pada budidaya udang, akan tetapi lebih berdampak terhadap pertumbuhan udang. Selain menginfeksi udang biru, penyakit ini juga menginfeksi udang putih $L$. vaname di beberapa negara lain seperti Brazil (Silva et.al 2014; Trindade et.al 2009) dan Amerika Utara (Lightner, 2011). Di Asia Tenggara, IHHNV pertamakali menyerang budidaya udang windu di Filipina. Hal ini disinyalir terkait importasi induk udang windu di negara tersebut untuk keperluan peningkatan produksi satu dekade sebelumnya (Lightner, 2011). Penyakit ini tidak menyebabkan kematian seperti jenis virus lain, akan tetapi menyebabkan penyakit fisik seperti Runt Deformity Syndrome yang mengakibatkan nilai ekonomi secara tidak langsung (Flegel, 2009). Pada penelitian saat ini, IHHNV ditemukan pada udang yang dibudidayakan di Kabupaten Tulang Bawang dan Lampung Timur. Dibandingkan jenis IMNV dan WSSV, sampel pengujian yang positif diakibatkan oleh jenis virus ini tergolong rendah. Hasil penelitian saat ini menguatkan temuan IHHNV pada tambak budidaya udang vaname wilayah Lampung Selatan (Sukenda et.al 2009). Lebih lanjut, selain terdapat pada udang yang dibudidayakan, IHHNV juga ditemukan pada saluran pengisian air ke tambak udang.

Pada penelitian ini ditemukan WSSV yang merupakan patogen penyebab WSD. Meskipun penyakit ini sudah umum pada budidaya udang vaname, dampak yang ditimbulkan akibat penyakit ini cukup besar. Pada kurun waktu 2019, penyakit ini diketahui menginfeksi sampel udang yang diambil dari seluruh wilayah sentra budidaya udang di Provinsi 
Lampung. Hal tersebut sesuai dengan temuan (Sukenda et.al 2009) yang menemukan bahwa WSSV ada di daerah Lampung Selatan. Selain di Provinsi Lampung, Latritiani et.al (2017) melaporkan bahwa WSSV sebagai penyabab WSD ditemukan di pertambakan udang vaname di Pekalongan, Jawa Tengah dengan prevalensi sebesar $37.5 \%$. Selain uji PCR, uji histologi juga mengkonfirmasi adanya inklusi dan hipertropi pada sel inti pada sampel udang. Hasil monitoring yang dilakukan oleh Muliani et.al (2007) terhadap udang windu dengan berbagai ukuran (benih, tokolan maupun induk) dari beberapa wilayah di Indonesia menunjukkan masih ada infeksi WSSV dengan nilai prevalensi penyakit WSD sebesar $22-100 \%$. Sama seperti IMNV, salinitas berpengaruh terhadap prevalensi WSSV (Rahma et.al 2014). Tingkat salinitas $30^{\circ} \mathrm{ppt}$ terbukti mengurangi tingkat prevalensi WSSV pada udang windu sehingga menekan tingkat kematian maksimal $20 \%$.

Kegiatan pengujian sampel CKIB memiliki jumlah pengujian tertinggi apabila dibandingkan dengan kegiatan pengujian sampel umum dan pengujian sampel pemantauan. Pada kegiatan pengujian sampel CKIB, hasil menunjukkan bahwa sampel uji tidak menunjukkan hasil positif baik pada virus target WSSV, IHHNV maupun IMNV. Berdasarkan asal sampel uji, kegiatan pemantauan memiliki sampel pengujian yang paling banyak yang berasal dari beberapa Kabupaten/kota yang ada di Provinsi Lampung yakni Kabupten Pesawaran, Tulang Bawang, Lampung Selatan, Lampung Timur, Tanggamus dan Pesisir Barat. Sedangkan untuk sampel pengujian CKIB berasal dari kabupaten Lampung Selatan dan Tanggamus. Untuk sampel umum berasal dari kabupaten Lampung Selatan, Lampung Timur dan Pesawaran.

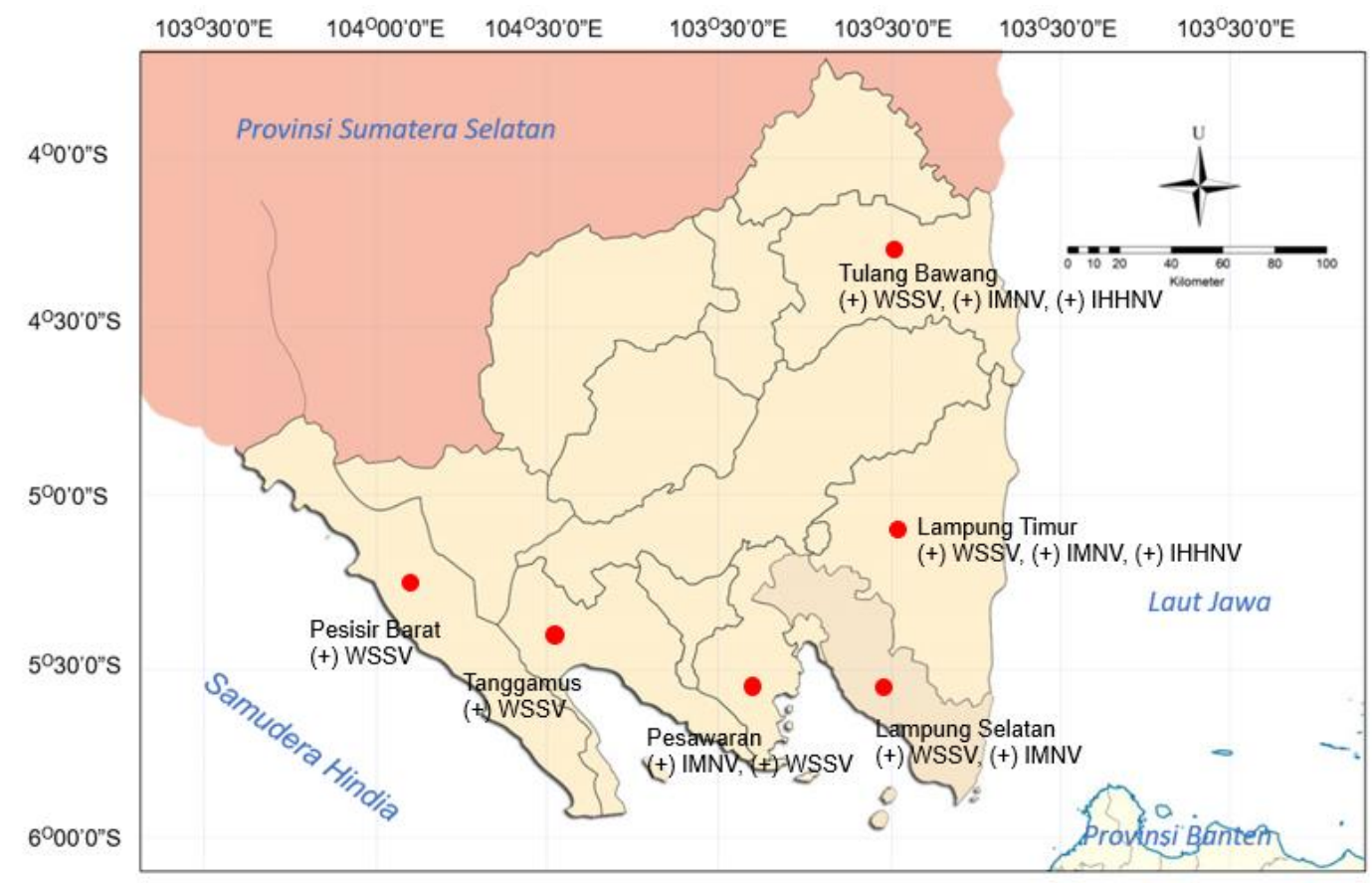

Gambar 3. Peta sebaran penyakit virus WSSV, IHHNV dan IMNV di Provinsi Lampung 
Dari keseluruhan sampel pengujian yang ada, diketahui bahwa dari kegiatan CKIB memberikan hasil pengujian yang negatif baik ntuk WSSV, IHHNV maupun IMNV. Hal tersebut dapat menjadi acuan bahwa dengan dilakukannya penerapan CKIB pada unit pembudidayaan udang termasuk hatchery dan tambak, cukup efektif untuk menekan penyebaran penyakit virus. Penerapan sistem CKIB yang dilakukan secara konsisten di unis usaha budidaya ikan hias telah dilaporkan oleh (Hernawati, 2018). Pada penelitiannya, dilaporkan bahwa penerapan program CKIB dapat menaikkan tingkat kelangsungan hidup hingga $80-90 \%$. Nilai tersebut lebih tinggi bila dibandingkan dengan nit usaha ikan hias yang tidak melakukan penerapan CKIB. Dari sisi usaha penekanan adanya penyakit, penerapan program CKIB juga dapat menekan tingkat prevalensi penyakit pada ikan hias pada usaha budidaya ikan hias di Kota Jambi. CKIB merupakan program karantina yang berbasis resiko. Pada penanganan hewan akuatik termasuk ikan, pencegahan penyakit telah diperkenalkan (Arthur, 2004; FAO, 2008; Murray et.al 2004). Pada sistem manajemen berbasis resiko, kejadian outbreak ditekan dengan input dan sistem pemeliharaan yang baik dan sesuai dengan standar prosedur yang berlaku (FAO, 2008). Karantina memiliki peran yang sangat penting dalam pencegahan beberapa penyakit ikan berbahaya di Asia Tengara (Arthur, 2004). Di Indonesia, program monitoring dan surveilan penyakit ikan telah dilakukan antara lain dengan melakukan pengujian histopatologi, emidemiolgi, diagnosa cepat (Sunarto et.al 2004). CKIB merupakan salah satu produk dari program monitoring dan surveilan yang pada penelitian ini memberikan dampak nyata terhadap penyebaran penyakit ikan khususnya virus pada udang vaname.

\section{KESIMPULAN}

Penyakit WSD, IHHN dan IMN msih terdapat pada budidaya udang vaname di Provinsi Lampung. Meskipun demikian, adanya penerapan CKIB pada unit usaha budidaya udang terbukti dapat menekan perkembangan penyakit virus tersebut. Dengan semakin meningkatnya proses produksi udang vaname di Provinsi Lampung, perlu adanya implementasi CKIB yang lebih masif untuk dilakukan. Hal ini bertujuan untuk menekan penyebaran penyakit virus pada udang sehingga kegiatan budidaya udang dapat berjalan dengan baik. 


\section{DAFTAR PUSTAKA}

Arthur, J. R. (2004, 23-24 June 2004). The Role of Quarantine in Preventing the Spread of Serious Pathogens of Aquatic Animals in Southeast Asia. Transboundary fish diseases in Southeast Asia: occurrence, surveillance, research and training. Paper presented at the Proceedings of the Meeting on Current Status of Transboundary Fish Diseases in Southeast Asia: Occurrence, Surveillance, Research and Training, Manila, Philippines.

Costa, A., Buglione, C., Bezerra, F., Martins, P., \& Barracco, M. (2009). Immune assessment of farm-reared Penaeus vannamei shrimp naturally infected by IMNV in NE Brazil. Aquaculture (Amsterdam, Netherlands), 291(3-4), 10.1016/j.aquaculture.2009.03.013.

FAO. (2008). Procedures for the quarantine of live aquatic animals $A$ manual. Roma, Italia: FAO.

FAO. (2018). The State of World Fisheries and Aquaculture 2014 (pp. 223). Rome: FAO.

FAO. (2020). Penaeus monodon. In H. Kongkeo (Ed.), Cultured Aquatic Species Information Programme. Rome: Food and Agriculture Organization.

Flegel, T. W. (2006). Detection of major penaeid shrimp viruses in Asia, a historical perspective with emphasis on Thailand. Aquaculture, 258(1), 1-33. doi: https://doi.org/10.1016/j.aquaculture.2006.05.013.

Flegel, T. W. (2009). Current Status of Viral Diseases in Asian Shrimp Aquaculture. Israeli Journal of Aquaculture - BAMIGDEH, 61(3), 229-239.

Hernawati, R. (2018). Efektivitas Penerapan Cara Karantina Ikan yang Baik (CKIB) untuk Pengendalian Penyakit Ikan Hias (Study Kasus Unit USaha Pembudidaya Ikan di Kota Jambi). (Master), Universitas Terbuka, Jakarta.

Inouye, K., Miwa, S., Oseko, N., Nakano, H., Kimura, T., Momoyama, K., \& Hiraoka, M. (1994). Mass mortalities of cultured kuruma shrimp Penaeus japonicus in Japan in 1993: Electron microscopic evidence of the causative virus. v. 29. 
Koesharyani, I., Gardenia, L., \& Mufidah, T. (2015). Sebaran Infeksi Taura Syndrome, Infectious Myonecrosis, dan Penaeus Vannamei Nervous Virus (TSV, IMNV, dan PVNV) pada Budidaya Udang Litopenaeus Vannamei di Jawa Barat, Jawa Timur, dan Bali. Jurnal Riset Akuakultur, 10, 415. doi: 10.15578/jra.10.3.2015.415-422.

Koesharyani, I., Gardenia, L., \& Supriyadi, H. (2012). Multi Infeksi pada Udang Litopenaeus Vannamei : Diagnosis dengan Polymerase Chain Reaction (PCR) Dan Reverse Transcriptase-Polymerase Chain Reaction (RT-PCR). Jurnal Riset Akuakultur, 7, 73. doi: 10.15578/jra.7.1.2012.73-84.

Latritiani, R., Desrina, \& Sarjito. (2017). Keberadaan White Spot Syndrome Virus (WSSV) pada Udang Vannamei (Litopenaeus Vannamei) di Pertambakan Kota Pekalongan. Journal of Aquaculture Management and Technology; Volume 6, Nomor 3, Tahun 2017.

Lightner, D. V. (2011). Virus diseases of farmed shrimp in the Western Hemisphere (the Americas): A review. Journal of Invertebrate Pathology, 106(1), 110-130. doi: https://doi.org/10.1016/j.jip.2010.09.012.

Mai, H. N., Hanggono, B., Caro, L. F. A., Komaruddin, U., Nur'aini, Y. L., \& Dhar, A. K. (2019). Novel infectious myonecrosis virus (IMNV) genotypes associated with disease outbreaks on Penaeus vannamei shrimp farms in Indonesia. (1432-8798 (Electronic)).

Mita, U., Sarjito, S., \& Desrina, D. (2016). Pengaruh Salinitas Terhadap Infeksi Infectious Myonecrosis Virus (Imnv) Pada Udang Vaname Litopenaeus Vannamei (Boone,1931). Journal of Aquaculture Management and Technology, 5(1), 73-81.

Muliani, Tampangallo, B. R., \& Atmomarsono, M. (2007). Penyebaran dan Prevalensi White Spot Syndrome Virus (WSSV) pada Budiaya Udang Windu (Penaeus monodon). Jurna Riset Akuakultur, 2(2).

Mulyadi, M., Handayani, C. R., Kusumaningrum, H. P., \& Budiharjo, A. (2013). Prediksi Resistensi Udang Vaname (Litopenaus vannamei) terhadap Infectious Hypodermal and Hematopoietic Necrosis Virus (IHHNV) dari Tambak Intensif dan Semi Intensif Jepara Menggunakan Marka RAPD. Bioma, 15(2), 73-80.

Murray, N., MacDiarmid, S., Wooldridge, M., Gummow, B., Morley, R., Weber, S., Wilson, D. (2004). Handbook on Import Risk Analysis for animals and animal products: introduction and qualitative risk analysis. 
Naim, S., Brown, J. K., \& Nibert, M. L. (2014). Genetic diversification of penaeid shrimp infectious myonecrosis virus between Indonesia and Brazil. Virus Research, 189, 97-105. doi: https://doi.org/10.1016/j.virusres.2014.05.013.

Nainggolan, H., Krisna Fery Rahmantya, Anggie Destiti Asianto, Dadang Wibowo, Tri Wahyuni, Ari Zunianto, . . . Rosna Malika. (2018). Marine And Fisheries In Figures 2018. The Center for Data, Statistics and Information.

Nakano, H., Koube, H., Umezawa, S., Momoyama, K., Hiraoka, M., Inouye, K., \& Oseko, N. (1994). Mass mortalities of cultured kuruma shrimp, Penaeus japonicus, in Japan in 1993: Epizootiological survey and infection trials. v. 29.

Nur'aini, Y. L., Hanggono, B., Subyakto, S., \& Triastutik, G. (2007). Survailen Aktif Infectious Myonecrosis Virus (Imnv) pada Udang Vannamei (Litopenaeus vannamei) yang Dibudidayakan di Jawa Timur Dan Bali. Jurnal Perikanan, 9(1).

Nurhajarini, D. R., Tugas Tri Wahyono, \& Dana Listiana. (2017). Perkembangan Budidaya Tambak Udang di Pesisir Tuban 1980 2015. Yogyakarta: Balai Pelestarian Nilai Budaya (BPNB) Yogyakarta.

OIE. (2006). Manual of diagnostic tests for Aquatic Animal diseases (O. I. d. Epizooties Ed. Fifth ed.). Paris, France: Office International des Epizooties.

Rahma, H. N., Prayitno, S. B., \& Haditomo, A. H. C. (2014). Infeksi White Spot Syndrom Virus (Wssv) pada Udang Windu (Penaeus Monodon Fabr.) yang Dipelihara pada Salinitas Media yang Berbeda. Journal of Aquaculture Management and Technology, $3(3)$.

Rekasana, A., Sulmartiwi, L., \& Soedarno. (2013). Distribusi Penyakit Infectious Myo Necrosis Virus (IMNV) pada Udang Vannamei (Litopenaeus Vannamei) di Pantai Utara Jawa Timur. Jurnal IImiah Perikanan dan Kelautan, 5(1), 49-54.

Rukyani, A. (2001). Indonesia. In R.P. Subasinghe, J.R. Arthur \& M. J. Philips (Eds.), The Thematic Review on Management Strategies for MAjor Diseases in Shrimp Aquaculture (pp. 135). Cebu, Philippines: The World Bank (WB), Network of Aquaculture Centres in AsiaPacific (NACA), World Wildlife Fund (WWF) and Food and Agriculture Organization of the United Nations (FAO) Consortium Program On Shrimp Farming And The Environment. 
Sarah, H., Prayitno, S. B., \& Haditomo, A. H. C. (2018). Studi Kasus Keberadaan Penyakit IMNV (Infectious Myonecrosis Virus) pada Udang Vaname (Litopenaeus Vannamei) di Pertambakan Pekalongan, Jawa Tengah. Sains Akuakultur Tropis : Indonesian Journal of Tropical Aquaculture; Vol 2, No 1 (2018). doi: 10.14710/sat.v2i1.2479.

Senapin, S., Phewsaiya, K., Briggs, M., \& Flegel, T. W. (2007). Outbreaks of infectious myonecrosis virus (IMNV) in Indonesia confirmed by genome sequencing and use of an alternative RT-PCR detection method. Aquaculture, 266(1), 32-38. doi: https://doi.org/10.1016/j.aquaculture.2007.02.026.

Silva, D. C. D., Nunes, A. R. D., Teixeira, D. I. A., Lima, J. P. M. S., \& Lanza, D. C. F. (2014). Infectious hypodermal and hematopoietic necrosis virus from Brazil: Sequencing, comparative analysis and PCR detection. Virus Research, 189, 136-146. doi: https://doi.org/10.1016/j.virusres.2014.05.008.

Sriwulan, \& Anshary, H. (2011). Deteksi Virus Penyebab Penyakit Kerdil pada Benih Udang Windu (Penaeus Monodon) Dengan Multipleks Pcr. Jurnal Perikanan, 8(1), 1-7.

Sudjito, Y. L., Christina, R. H., Hermin, P., Kusumaningrum., \& Anto, B. (2014). Karakterisasi Genetik Fragmen Gen Penyandi RNA Polimerase Infectious Myonecrosis Virus (IMNV) yang Menginfeksi Udang Vannamei (Litopenaeus vannamei Boone.) dari Lampung, Gresik dan Pontianak. Bioma, 16(1), 18-25.

Sukenda, S. H. Dwinanti, \& M. Yuhana. (2009). Existing of White Spot Syndrome Virus (WSSV), Taura Syndrome Virus (TSV) and Infectious Hypodermal Haematopoitic Necrosis Virus (IHHNV) in White Shrimp Litopenaeus vannamei Reared at Intensive Tambak System in Bakauheni, Lampung Selatan. Jurnal Akuakultur Indonesia, 8(2), 1-8.

Sunarto, A., Widodo, Taukhid, Koesharyani, I., Supriyadi, H., Gardenia, L., . . . views, P. (2004, 23-24 June 2004). Current status of transboundary fish diseases in Indonesia: Occurrence, surveillance, research and training Paper presented at the Proceedings of the Meeting on Current Status of Transboundary Fish Diseases in Southeast Asia: Occurrence, Surveillance, Research and Training, Manila, Philippines.

Taukhid, \& Nur'aini, Y. L. (2008). Infectious Myonecrosis Virus (IMNV) in Pacific White Shrimp, Litopenaeus vannamei in Indonesia. Indonesian Aquaculture Journal, 3(2), 139-146. 
Trindade, I. M. S., Ribas, J. R. L., Mendonça, F. F., Santos, S. C. H. I., \& Leal, R. F. (2009). Primeiro registro oficial do vírus da necrose hipodérmica hematopoiética infecciosa dos camarões no Brasil.

Wyban, J., \& Sweeney, J. N. (1991). Intensive shrimp production technology: the Oceanic Institute shrimp manual.

Yanti, M. E. G., Herliany, N. E., Negara, B. F., \& Utami, M. A. F. (2017). Deteksi Molekuler White Spot Syndrome Virus (WSSV) pada Udang Vaname (Litopenaeus Vannamei) Di PT. Hasfam Inti Sentosa. Jurnal Enggano, 2(2).

Zaujat, R. C., Setiyaningsih, S., \& Lusiastut, i. M. (2016). Prevalensi dan Karakterisasi Molekuler Infectious Myonecrosis Virus(IMNV) di Sentra Budidaya Udang Vaname (Litopenaeus Vannamei) Propinsi Banten. Acta Veterinaria Indonesiana, 4(2), 88-96. 